\section{Transfusion and risk of infection in Canada: Update 2006}

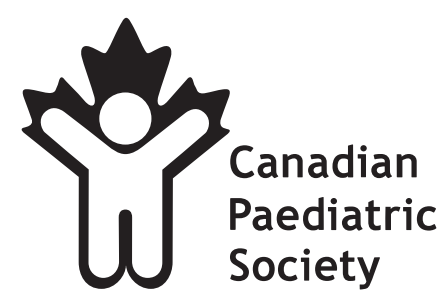

- the effectiveness of donor screening or donor testing for the agent; and

- the effectiveness of the aseptic technique used in collecting the blood or blood product from the donor and in infusing the product into the recipient.

In Canada, the infectious disease risks associated with transfusion are minimized through multiple steps, including blood collection from unpaid volunteer donors; donor interview and selection procedures; careful aseptic techniques for collection and infusion; diversion of the first $40 \mathrm{~mL}$ of blood collected into a diversion pouch (12); donor screening by serological and other tests, including bacterial detection in platelets (Table 1); viral inactivation procedures included in the manufacturing of plasma-derived products (Table 2) (13-15); and leukocytereduction techniques that reduce the infection transmission risk of white blood cell-associated viruses, such as cytomegalovirus (16). Unfortunately, the solvent or detergent and heat viral inactivation procedures noted in Table 2 cannot be used on red blood cells or platelets because neither can withstand these vigorous processes.

Table 3 identifies specific inactivation steps in the manufacturing of different plasma-derived products that decrease viral infection risks. Of note, the majority of factor VIII and factor IX used in Canada are recombinant products, not plasma-derived, and, hence, do not have the infectious risks of a blood product.

TABLE 1

Testing of blood donors in Canada by Canadian Blood Services (CBS) and Héma-Québec*

sion - are also effective in minimizing blood and blood product use (9).

Effective evidence-based policies for donor selection, screening, product collection, testing and infusion While any infectious agent that has a blood phase has the potential to be transmitted by the transfusion of blood or blood products, the probability of infection in the recipient depends on a number of factors, including the following $(6,10,11)$ :

- the prevalence of the agent in the blood of the donor population;

- the tolerance of the agent to blood handling, storage and manufacturing processes;

- the infectivity and pathogenicity of the agent;

- the recipient's health and immune status;

\begin{tabular}{ll}
\hline Microbiological agent & Test \\
\hline HIV-type $1 / 2 / 0^{\dagger}$ group & Antibody/NAT \\
HBV & Hbs Ag, Anti-HBc \\
HTLV type I/II & Antibody \\
Syphilis & Treponemal test/PK-TP \\
HCV & Antibody/NAT \\
WNV & NAT \\
Bacteria & Bacterial culture on platelets ${ }^{\ddagger}$ \\
Other & CMV antibody on selected units only \\
\hline
\end{tabular}

*Personal communications: Dr Gilles Delage, Héma-Québec, and Dr Heather Hume; 'While the PRISM HIV antibody test does detect HIV group O, donors are still asked questions related to travel to parts of the world where HIV-O infection

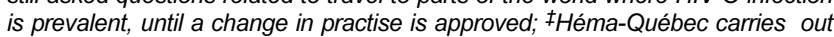
bacterial culture testing of all platelet products and CBS does this for apheresis platelets. CMV Cytomegalovirus; HBc Hepatitis B core antigen; Hbs Ag Hepatitis $B$ surface antigen; HBV Hepatitis B virus; HCV Hepatitis C virus; HTLV Human T-lymphotropic viruses; NAT Nucleic acid testing; WNV West Nile virus

Correspondence: Dr Noni MacDonald, Department of Paediatrics, IWK Health Centre, 5840 University Avenue, Halifax, Nova Scotia B3J 3G9. Telephone 902-470-8799, fax 902-470-7812,e-mail noni.macdonald@dal.ca 
TABLE 2

Specific manufacturing procedures for virus inactivation or removal

\begin{tabular}{ll}
\hline Procedure & Agents inactivated \\
\hline Inactivation by heat & CMV, HAV, HBV, HCV, HIV, WNV, Parvovirus B19 \\
Inactivation by solvent/detergent & CMV, HBV, HCV, HIV, WNV \\
Ultrafiltration using $35 \mathrm{~nm}$ and $15 \mathrm{~nm}$ filters & Removes even small viruses but also macromolecules \\
& (eg, factor VIII is decreased) \\
Leukocyte depletion & Decreases CMV, HTLV type I/II
\end{tabular}

CMV Cytomegalovirus; HAV Hepatitis A virus; HBV Hepatitis B virus; HCV Hepatitis C virus; HTLV Human T-lymphotropic viruses; WBC White blood cell; WNV West Nile virus

TABLE 3

Manufacturing steps to decrease infectious risks of plasma preparations and plasma-derived components

\begin{tabular}{|c|c|c|c|}
\hline Plasma preparation & $\begin{array}{l}\text { Virus risk } \\
\text { preinactivation } \\
\text { process(es) }\end{array}$ & $\begin{array}{c}\text { Pools screened for } \\
\text { HIV, HCV, HBV } \\
\text { and HTLV type I/II* }\end{array}$ & Further virus inactivation steps \\
\hline $\begin{array}{l}\text { Cryoprecipitate (a blood } \\
\text { component, not a } \\
\text { fractionation product) }\end{array}$ & ++ & Yes & None $^{\dagger}$ \\
\hline Factor VII & + & Yes & Heat inactivation \pm solvent/detergent \\
\hline Factor VIII & + & Yes & Heat inactivation \pm solvent/detergent \\
\hline Factor IX $\ddagger$ & + & Yes & Heat inactivation, solvent/detergent, chromatography, ultrafiltration \\
\hline Antithrombin concentrates & + & Yes & $\mathrm{COHN}$ fractionation, heat inactivation, chromatography \\
\hline Albumin & + & Yes & COHN fractionation, heat inactivation \\
\hline IVIG products & + & Yes & $\begin{array}{l}\text { COHN fractionation, } \pm \text { hydrolase, } \pm \text { solvent/detergent, } \pm \text { heat inactivation, } \\
\pm \text { chromatography, nanofiltration, } \pm \text { caprylate }\end{array}$ \\
\hline IMIG & + & Yes & $\mathrm{COHN}$ fractionation, solvent/detergent, heat treatment, nanofiltration, \pm chromatography \\
\hline Specific antibody products§ & + & Yes & $\begin{array}{l}\mathrm{COHN} \text { fractionation or ion exchange column chromatography, solvent/detergent, } \\
\text { filtration } \pm \text { heat inactivation }\end{array}$ \\
\hline
\end{tabular}

*Human T-lymphotropic viruses (HTLV) type I/II are cell-associated viruses, so they are not found in manufactured plasma-derived products, and serological screening of source plasma is not required. Similarily, cytomegalovirus (CMV) is primarily cell-associated, and the manufacturing processes remove risk; ${ }^{\dagger}$ The risk of transmission of infection from cryoprecipitate is similar to the risk from blood and blood products and greater than from plasma-derived manufactured products; ¥Very few patients in Canada are treated with plasma-derived factor VII or factor IX; §Includes hepatitis B (HBV) immune globulin, tetanus immune globulin, rabies immune globulin and Rh (D) immune globulin. HCV Hepatitis C virus; IMIG Intramuscular immunoglobulin; IVIG Intravenous immunoglobulin

Bacterial contamination of platelets is greater than that with red blood cells because platelets are stored at room temperature $\left(22 \pm 2^{\circ} \mathrm{C}\right)$, which supports bacterial pathogen multiplication $(17,18)$. Various strategies have been developed to try to minimize the risk of transfusion-associated sepsis, including enhanced aseptic collection and handling procedures, pretransfusion bacterial detection systems, processing and storage enhancement procedures and pathogen inactivation techniques $(19,20)$. While the use of closed, multicomponent, plastic blood pack collection systems has helped to decrease the problem, bacterial contamination of platelet concentrates is still a concern (20). The risk of bacterial contamination of frozen components, such as fresh frozen plasma and cryoprecipitates, is now low because the usual microbes (Table 4) are killed by freezing and other storage conditions. Where plasma has been found to be the source of infection, it was usually due to contamination of the water bath used to thaw the product (21). The use of microwave techniques or appropriate plastic covering specifically designed for this purpose minimizes this risk.

\section{ATEs IN CANADA}

The Transfusion Transmitted Injuries Surveillance System (TTISS) in Canada began as a pilot project in four
TABLE 4

\begin{tabular}{|c|c|c|}
\hline Blood component & Storage & Bacterial agent \\
\hline Packed red cells & $\begin{array}{l}1^{\circ} \mathrm{C} \text { to } 6^{\circ} \mathrm{C} \text { for } 35 \text { to } \\
42 \text { days }\end{array}$ & $\begin{array}{l}\text { Yersinia enterocolitica } \\
\text { Gram-negative organisms, } \\
\text { including Pseudomonas species }\end{array}$ \\
\hline Whole blood & $\begin{array}{l}1^{\circ} \mathrm{C} \text { to } 6^{\circ} \mathrm{C} \text { for } 35 \text { to } \\
42 \text { days }\end{array}$ & Gram-negative organisms \\
\hline Platelets & $\begin{array}{l}20^{\circ} \mathrm{C} \text { to } 24^{\circ} \mathrm{C} \text { for } \\
\text { five days }\end{array}$ & $\begin{array}{l}\text { Skin flora (eg, Staphylococcus } \\
\text { epidermidis, Streptococcus } \\
\text { species, Diptheroids) } \\
\text { Salmonella species } \\
\text { Escherichia coli } \\
\text { Enterococci species } \\
\text { Clostridium species } \\
\text { Serratia marcescens }\end{array}$ \\
\hline Plasma & $\begin{array}{l}\text { Frozen, once thawed } \\
\text { can be held at } 1^{\circ} \mathrm{C} \\
\text { to } 6^{\circ} \mathrm{C} \text { for } 24 \mathrm{~h}\end{array}$ & $\begin{array}{l}\text { Staphylococcus aureus } \\
\text { Pseudomonas aeruginosa }\end{array}$ \\
\hline
\end{tabular}

provinces in 1999 to look for serious adverse events with receipt of blood or blood product infusions. TTISS is now a national program in various stages of implementation in all provinces and territories (4). This program has led to an 


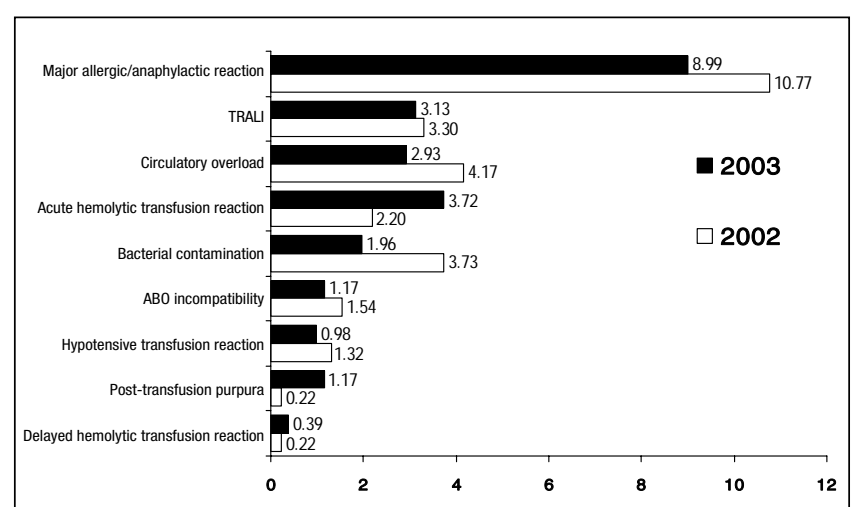

Figure 1) Comparative rates of adverse transfusion events per 100,000 units of blood transfused in Canada in 2002 and 2003. TRALI Transfusion-related acute lung injury. Reproduced from reference 4

improvement in the quality and timeliness of risk estimates for ATEs.

The latest TTISS program report (4), covering the years 2002 and 2003, notes that a total of 1,629,684 units were transfused in the participating hospitals; 512 ATEs were reported, $296(57.8 \%)$ of which met the surveillance case definitions. Of these, 36 (12.2\%) occurred in those younger than 17 years. Overall, $51.3 \%$ of the ATEs were life threatening (rate 8.4 per 100,000 units) (4). As shown in Figure 1, the most common reported ATEs were major allergic or anaphylactic reactions (36\%; rate 5.9 per 100,000 units). Bacterial contamination was the reported ATE in $10.1 \%$ (rate 1.7 per 100,000 units) (see Figure 2 for microbe types) (4). Of the 27 cases of bacterial contamination, 10 (37.0\%) were related to red blood cells, 10 (37.0\%) to whole bloodderived platelets, two $(7.4 \%)$ to apheresis platelets and five (18.5\%) to plasma (4). Of the 11 case fatalities related to transfusion (two definite, seven probable and two possible; overall rate one per 100,000 units and definitely related rate one per 483,245 units), bacterial contamination was

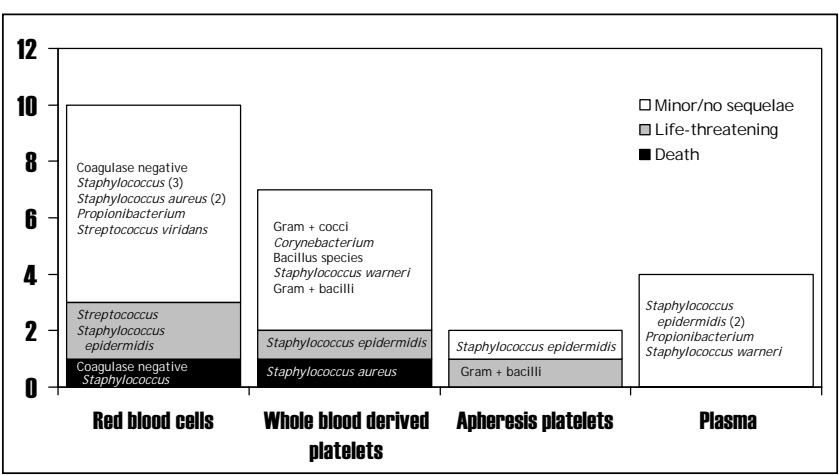

Figure 2) Cases of bacteria identified in blood product cultures in Canada in 2002 and 2003. Reproduced from reference 4

involved in three (one definite and two probable). The incidence of ATEs by type of blood component in 2003 is shown in Table 5.

Thus, the TTISS program has verified that there is a high degree of safety in the Canadian blood system, with only small risks of bacterial contamination, and that allergic or anaphylactic reactions remain as the major concern.

\section{ESTIMATED PER UNIT RISKS OF BACTERIAL, PARASITIC AND VIRAL CONTAMINATION OF BLOOD AND BLOOD PRODUCTS}

The estimated per unit risks of contamination in blood, blood products and manufactured plasma-derived products in Canada for a number of viral, bacterial, parasitic, prion and tick-borne agents are presented in Tables 6 and 7 . Where Canadian data were not available, data from the United States and other countries have been included $(5,10,11,14,22-24)$. As the data in Tables 6 and 7 show, the risks in Canada of transmitting infectious agents by blood, especially by plasma-manufactured products, are extremely low. To put it into context, a one in 3,000,000 risk is similar to that of being hit by lightning.

\section{TABLE 5}

Incidence in Canada of adverse transfusion events by blood component transfused in 2003

\begin{tabular}{|c|c|c|c|c|c|c|}
\hline \multirow[b]{3}{*}{ Adverse transfusion event } & \multicolumn{6}{|c|}{ Blood component } \\
\hline & \multirow[b]{2}{*}{$\begin{array}{c}\text { Red blood cells } \\
(n=326,903)\end{array}$} & \multicolumn{2}{|c|}{ Whole blood-derived platelets } & \multirow[b]{2}{*}{$\begin{array}{c}\text { Apheresis platelets } \\
(n=11,694)\end{array}$} & \multirow[b]{2}{*}{$\begin{array}{c}\text { Plasma } \\
(\mathrm{n}=98,914)\end{array}$} & \multirow[b]{2}{*}{$\begin{array}{c}\text { All products* } \\
(\mathrm{n}=511,364)^{\dagger}\end{array}$} \\
\hline & & $\begin{array}{c}\text { Units } \\
(n=155,944)\end{array}$ & $\begin{array}{c}\text { Pools of five } \\
(n=31,189)\end{array}$ & & & \\
\hline Major allergic or anaphylactic reaction & $1: 23,350$ & $1: 19,493$ & $1: 3889$ & $1: 2339$ & $1: 6182$ & $1: 11,117^{\ddagger}$ \\
\hline TRALI & $1: 46,700$ & $1: 77,972$ & $1: 15,595$ & - & $1: 19,783$ & $1: 31,960^{\ddagger}$ \\
\hline Circulatory overload & $1: 32,690$ & - & - & - & $1: 32,971$ & $1: 34,091^{\ddagger}$ \\
\hline Bacterial contamination & $1: 65,381$ & $1: 155,944$ & $1: 31,189$ & $1: 5847$ & $1: 49,457$ & $1: 51,136$ \\
\hline ABO incompatibility & $1: 108,968$ & $1: 77,972$ & $1: 15,595$ & - & $1: 98,914$ & $1: 85,227$ \\
\hline Hypotensive transfusion reaction & $1: 108,968$ & - & - & - & $1: 98,914$ & $1: 102,273^{\ddagger}$ \\
\hline Post-transfusion purpura & $1: 108,968$ & $1: 155,944$ & $1: 31,189$ & - & - & $1: 85,227^{\ddagger}$ \\
\hline Delayed hemolytic transfusion reaction & $1: 163,452$ & - & - & - & - & $1: 255,682$ \\
\hline
\end{tabular}

*Include cryoprecipitate and granulocytes; ${ }^{+}$Whole blood-derived platelets were counted as pools of five; ${ }^{\ddagger}$ Includes adverse transfusion events to multiple components, no single unit being related to the event; §Includes three cases of ABO incompatibility resulting in acute hemolytic reactions. TRALI Transfusion-related acute lung injury. Data from reference 4 


\section{TABLE 6}

\section{Estimated risk of infectious agent blood or blood products}

\begin{tabular}{|c|c|c|c|}
\hline Agent or product & Transfusion-transmitted & Pathogenic & Canadian estimated risk of contamination* \\
\hline \multicolumn{4}{|c|}{ Viruses for which all blood donors are tested } \\
\hline $\mathrm{HIV}^{\dagger}$ & Yes & Yes & Less than one in $4,000,000$ \\
\hline $\mathrm{HBV}^{\dagger}$ & Yes & Yes & One in 82,000 to one in 275,000 \\
\hline HTLV† type I/II & Yes & Yes & Less than one in $1,000,000$ \\
\hline WNV & Yes & Yes & No reported cases in Canada since screening introduced in $2003^{\ddagger}$ \\
\hline CMV & Yes & Yes & Risks vary with donor and recipient but are rare§ \\
\hline Parvovirus B19 & Yes & Yes & One in 5000 to one in 20,000 \\
\hline GBV-C ${ }^{\dagger}$ & Yes & Unknown & One to two in 100; not known to be pathogenic \\
\hline $\mathrm{TTV}^{\dagger}$ & Yes & Unknown & One in 100 ; rarely pathogenic \\
\hline SEN-V ${ }^{\dagger}$ & Yes & Unknown & One in 100; not known to be pathogenic \\
\hline Chagas (Trypanosoma cruzi) & Yes & Yes & Two cases reported in Canada in past 15 years \\
\hline Babesiosis (Babesia microti) & Yes & Yes & One case reported in Canada in past 15 years \\
\hline \multicolumn{4}{|l|}{ Prion } \\
\hline vCJD & Unknown & Yes & Risk unknown, extremely rare less than one in $10,000,000$ \\
\hline
\end{tabular}

${ }^{*}$ Risk of contamination refers to the potential residual risk of infection from the listed organisms in blood or blood products after proper screening and manufacturing processes have occurred; ${ }^{\dagger}$ Based on residual risk calculations published by Canadian Blood Services and Héma-Québec; $¥$ West Nile virus (WNV) not tested in Quebec in winter; §Cytomegalovirus (CMV) infection risk is decreased by leukoreduction procedures (see text). HBV Hepatitis B virus; HCV Hepatitis C virus; HHV-8 Human herpes virus 8; HTLV Human T-lymphotropic viruses; GBV-C Formerly named hepatitis G virus; TTV Transfusion-transmitted virus; vCJD Variant CreutzfeldtJakob disease

\section{IMPORTANCE OF DOCUMENTATION OF TRANSFUSION}

Experience gained from hepatitis C and HIV trace-back and look-back programs, where authorities have tried to trace transfusion recipients, have shown that many patients are unaware that they actually received a transfusion. No national electronic record of transfusions exists to facilitate any potential future tracing programs for a new transmissible agent. Therefore, it is important to make sure that transfused patients are aware that they received blood, blood products or manufactured plasma-derived products, and that the discharge or outpatient note adequately documents these transfusions and records the label code numbers for the specific products used.

\section{RESOURCES FOR MORE INFORMATION ON \\ INFECTIOUS DISEASES TRANSFUSION RISKS}

Expanded discussion on infectious diseases risks of transfusion of blood and blood products can be found at the following Web sites:

Canadian Blood Services: Transfusion Medicine. $<$ www.transfusionmedicine.ca>

Héma-Québec: Circular of information: For the use of Labile Blood Products, June 2005 Edition. <http://www.hemaquebec.qc.ca/media/anglais/publications/notice_ANG_ complet.pdf>

Public Health Agency of Canada: Transfusion Transmitted Injuries Section About Risks of Blood Transfusion. <www.phac-aspc.gc.ca/hcai-iamss/tti-it/risks_e.html>
TABLE 7

Estimated risks of infectious agents in manufactured plasma-derived products

$\begin{array}{ccc}\text { Historical evidence } & \\ \text { of transmission from } \\ \text { plasma product }\end{array}$ Pathogenic $\quad \begin{gathered}\text { Canadian estimated } \\ \text { risk of contamination* }\end{gathered}$

Viruses for which all blood donors are tested

$\begin{array}{lccl}\text { HIV } & \text { Yes } & \text { Yes } & \text { Less than one in 10,000,000 } \\ \text { HCV } & \text { Yes } & \text { Yes } & \text { Less than one in 10,000,000 } \\ \text { HBV } & \text { Yes } & \text { Yes } & \text { Less than one in 10,000,000 } \\ \text { HTLV type I/II } & \text { Yes } & \text { Yes } & \text { Only theoretical risk }\end{array}$

Other viruses

CMV No Yes Only theoretical risk

Parvovirus B19 Yes Yes Only theoretical risk if

heat inactivation;

otherwise, one in 100,000

to one in $1,000,000$

$\begin{array}{llll}\begin{array}{lll}\text { WNV } \\ \text { Parasites }\end{array} & \text { Yos } & \text { Only theoretical risk } \\ \begin{array}{c}\text { Malaria } \\ \text { Chagas }\end{array} & \text { No } & \text { Yes } & \text { Only theoretical risk } \\ \begin{array}{c}\text { Babesiosis } \\ \text { Prion }\end{array} & \text { No } & \text { Yes } & \text { Only theoretical risk } \\ \text { vCJD } & \text { Unknown } & \text { Yes } & \text { Only theoretical risk } \\ & & & \\ & & & \text { Theoretical risk of less } \\ \text { than one in 100,000,000 }\end{array}$

${ }^{*}$ Risk of contamination refers to the potential residual risk of infection from the listed organisms in plasma-derived products after proper screening and correct manufacturing processes have taken place. CMV Cytomegalovirus; HBV Hepatitis B virus; HCV Hepatitis C virus; HTLV Human T-lymphotropic viruses; vCJD Variant Creutzfeldt-Jakob disease; WNV West Nile virus 


\section{REFERENCES}

1. Strong DM, Katz L. Blood-bank testing for infectious diseases: How safe is blood transfusion? Trends Mol Med 2002;8:355-8.

2. Murphy WG. Disease transmission by blood products: Past, present and future. Pathophysiol Haemost Thromb 2002;32(Suppl 1):1-4.

3. Canadian Paediatric Society, Committee on Infectious Diseases and Immunization. Transfusion and risk of infection in Canada: Update 2005. Paediatr Child Health 2005;10:149-53.

4. Public Health Agency of Canada. Transfusion Transmitted Injuries Surveillance System: Program Report 2002-2003. <http://www.phacaspc.gc.ca/hcai-iamss/tti-it/pr-re0304/toc_e.html> (Version current at February 24, 2006).

5. Kleinman S, Chan P, Robillard P. Risks associated with transfusion of cellular blood products in Canada. Transfus Med Rev 2003;17:120-62.

6. Hebert PC, Wells G, Blajchman MA, et al; Transfusion Requirements in Critical Care Investigators, Canadian Critical Care Trials Group. A multicenter, randomized, controlled clinical trial of transfusion requirements in critical care. $\mathrm{N}$ Engl J Med 1999;340:409-17. (Erratum in 1999;340:1056)

7. Canadian Paediatric Society, Fetus and Newborn Committee. Red blood cell transfusions in newborn infants: Revised guidelines. Paediatr Child Health 2002;7:553-8.

8. Kirpalani H, Whyte R, Anderson C, et al. Conservative transfusion regimens are not associated with higher mortality or morbidity in ELBW infants - The Premature In Need of Transfusion (PINT) randomized controlled trial. Pediatric Academic Societies meeting. San Francisco, May 1 to 4, 2004.

9. Freedman J, Luke K, Monga N, et al. A provincial program of blood conservation: The Ontario Transfusion Coordinators (ONTraC). Transfus Apher Sci 2005;33:343-9.

10. Holness L, Knippen MA, Simmons L, Lachenbruch PA. Fatalities caused by TRALI. Transfus Med Rev 2004;18:184-8.

11. Blood safety: Reducing the risk of transfusion-transmitted infections. In: Red Book: Report of the Committee on Infectious Diseases, 25th edn. Elk Grove Village: American Academy of Pediatrics, 2000:88-97.

12. McDonald CP, Roy A, Mahajan P, Smith R, Charlett A, Barbara JA. Relative values of the interventions of diversion and improved donor-arm disinfection to reduce the bacterial risk from blood transfusion. Vox Sang 2004;86:178-182.

13. Busch MP. Closing the windows on viral transmission by blood transfusion. In: Stramer SL, ed. Blood Safety in the New Millennium. Bethesda: American Association of Blood Banks, 2001.

14. Guertler L. Virus safety of human blood, plasma, and derived products. Thromb Res 2002;107(Suppl 1):S39-45.

15. Blumel J, Schmidt I, Willkommen H, Lower J. Inactivation of parvovirus B19 during pasteurization of human serum albumin Transfusion 2002;42:1011-8.

16. Laupacis A, Brown J, Costello B, et al. Prevention of posttransfusion $\mathrm{CMV}$ in the era of universal WBC reduction: A consensus statement. Transfusion 2001;41:560-9.

17. Blajchman MA. Incidence and significance of the bacterial contamination of blood components. Dev Biol (Basel) 2002;108:59-67.

18. Blajchman MA, Goldman M, Baeza F. Improving the bacteriological safety of platelet transfusions. Transfus Med Rev 2004;18:11-24.

19. Seghatchian J. Bacterial contamination of blood components. Transfus Apher Sci 2001;25:147-50.

20. Ramirez-Arcos S, Goldman M. Evaluation of pooled cultures for bacterial detection in whole blood-derived platelets. Transfusion 2005;45:1275-9.

21. Churchill WH, Schmidt B, Lindsey J, Greenberg M, Boudrow S, Brugnara C. Thawing fresh frozen plasma in a microwave oven. A comparison with thawing in a 37 degrees $C$ waterbath. Am J Clin Pathol 1992;97:227-32.

22. Chiavetta JA, Escobar M, Newman A, et al. Incidence and estimated rates of residual risk for HIV, hepatitis $\mathrm{C}$, hepatitis $\mathrm{B}$ and human T-cell lymphotropic viruses in blood donors in Canada, 1990-2000. CMAJ 2003;169:767-73.

23. Tabor E. The epidemiology of virus transmission by plasma derivatives: Clinical studies verifying the lack of transmission of hepatitis $\mathrm{B}$ and $\mathrm{C}$ viruses and HIV type 1 . Transfusion 1999;39:1160-8.

24. Germain M, Gelinas S, Delage G. Estimation of risk of windowperiod transmission of blood-borne viral diseases in Quebec. CMAJ 2004;170:1077-8.

\section{INFECTIOUS DISEASES AND IMMUNIZATION COMMITTEE (2005-2006)}

Members: Drs Simon Richard Dobson, BC's Children's Hospital, Vancouver, British Columbia; Joanne Embree, The University of Manitoba, Winnipeg, Manitoba (chair); Joanne Langley, IWK Health Centre, Halifax, Nova Scotia; Dorothy Moore, The Montreal Children's Hospital, Montreal, Quebec; Gary Pekeles, The Montreal Children's Hospital, Montreal, Quebec (board representative); Élisabeth Rousseau-Harsany, Hôpital Sainte-Justine, Montreal, Quebec (board representative); Lindy Samson, Children's Hospital of Eastern Ontario, Ottawa, Ontario

Consultant: Dr Noni MacDonald, Department of Pediatrics, IWK Health Centre, Halifax, Nova Scotia

Liaisons: Drs Upton Allen, The Hospital for Sick Children, Toronto, Ontario (Canadian Pediatric AIDS Research Group); Scott Halperin, IWK Health Centre, Halifax, Nova Scotia (IMPACT); Monica Naus, BC Centre for Disease Control, Vancouver, British Columbia (Health Canada, National Advisory Committee on Immunization); Larry Pickering, Centers for Disease Control and Prevention, Atlanta, Georgia, USA (American Academy of Pediatrics, Committee on Infectious Diseases)

Principal authors: Dr Noni MacDonald, Dalhousie University, Halifax, Nova Scotia; JW Scott, Department of Health, Halifax, Nova Scotia; Ms Nancy McCombie, Transfusion Transmitted Injuries Section Blood Safety Surveillance and Health Care Acquired Infections Division, Centre for Infectious Disease Prevention and Control, Public Health Agency of Canada; Dr Pierre Robillard, Transfusion Transmitted Injuries Section Blood Safety Surveillance and Health Care Acquired Infections Division, Centre for Infectious Disease Prevention and Control, Public Health Agency of Canada; Dr Antonio Giulivi, Hematology and Transfusion Medicine, The Ottawa Hospital, Ottawa, Ontario

The recommendations in this statement do not indicate an exclusive course of treatment or procedure to be followed. Variations, taking into account individual circumstances, may be appropriate. Internet addresses are current at time of publication. This article has also appeared in a previous issue of Paediatrics $\mathbb{E}$ Child Health (Paediatr Child Health 2006;11:158-62). 


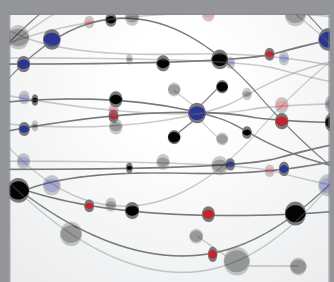

The Scientific World Journal
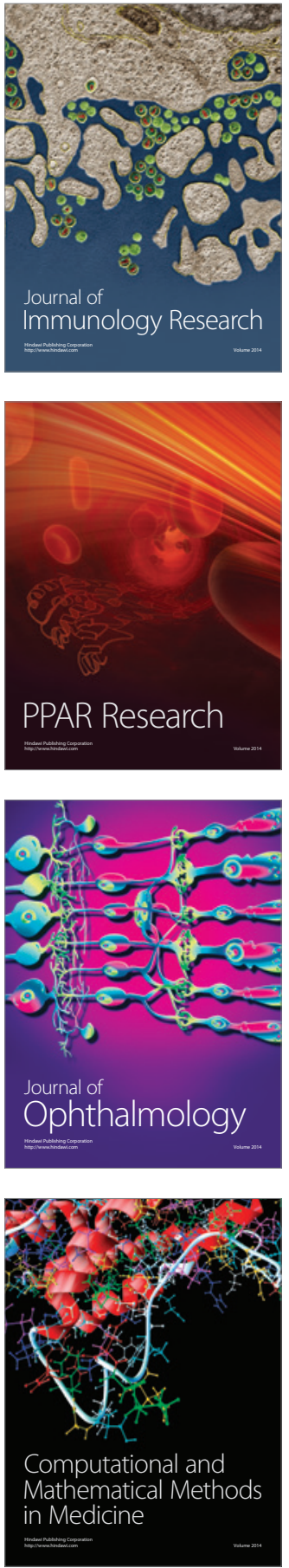

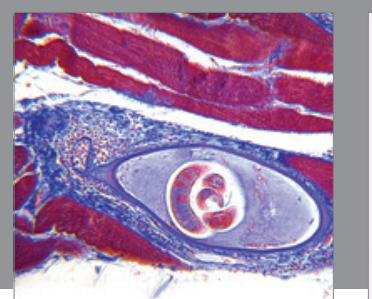

Gastroenterology Research and Practice

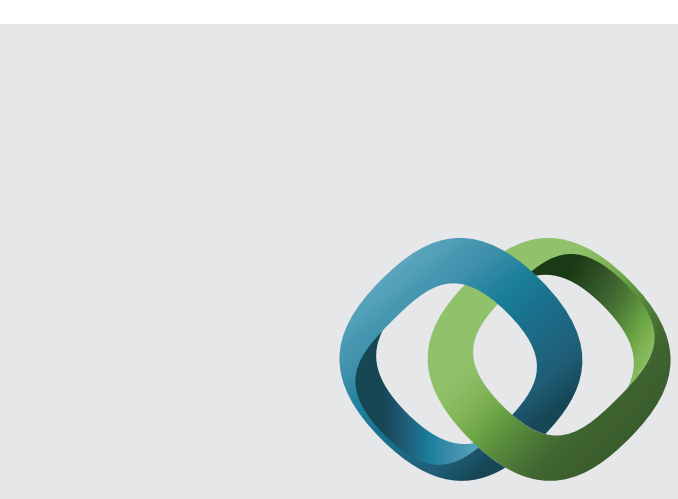

\section{Hindawi}

Submit your manuscripts at

http://www.hindawi.com
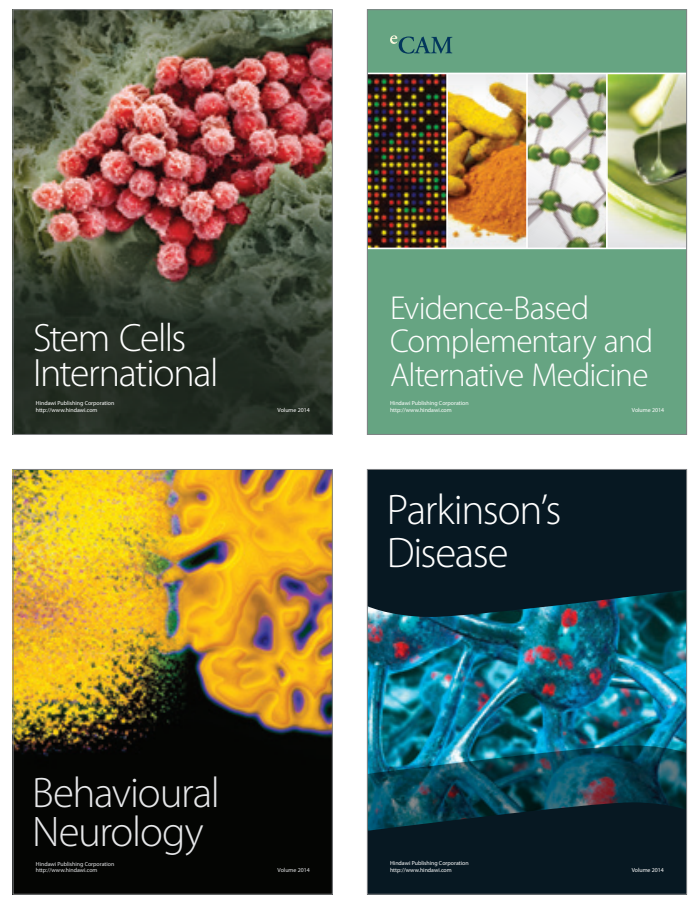
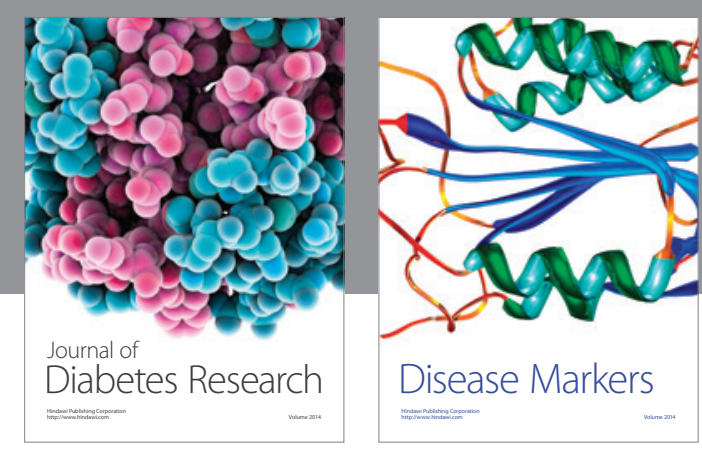

Disease Markers
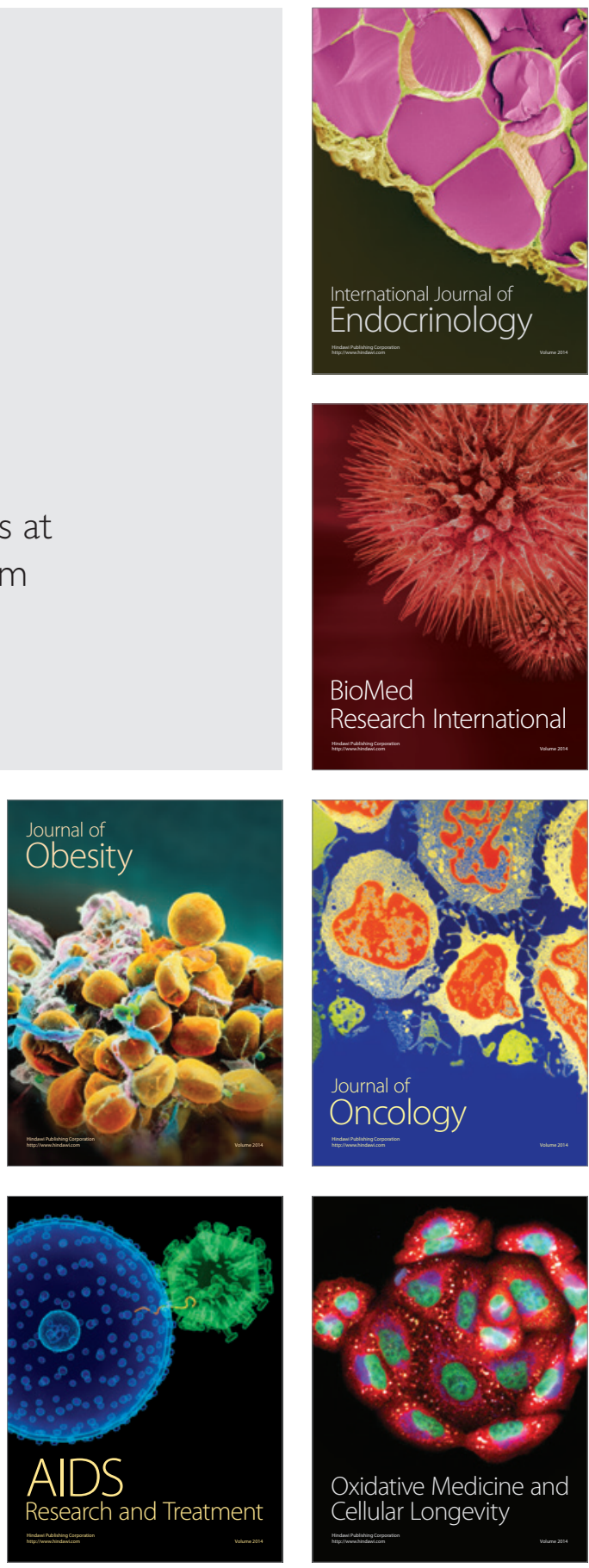